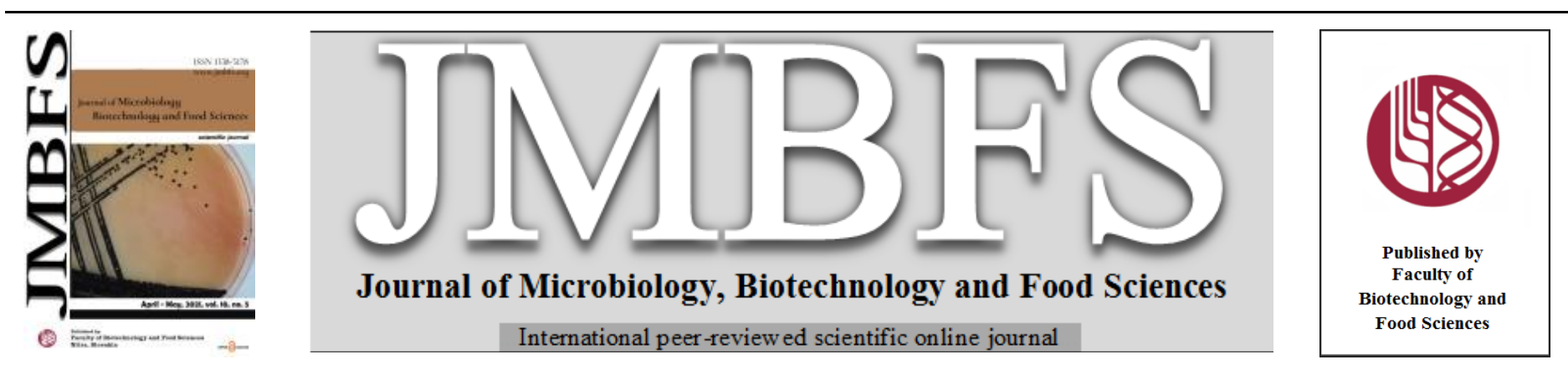

\title{
PSYCHROPHILIC MICROBIAL DIVERSITY AND PHYSICOCHEMICAL CHARACTERISTICS OF GLACIERS IN THE GARHWAL HIMALAYA, INDIA
}

\author{
Rahul Kumar* and Ramesh C. Sharma
}

Address(es):

Laboratory of Environmental Microbiology and Biotechnology, Department of Environmental Sciences, H.N.B. Garhwal University (A Central University), Srinagar Garhwal- 246174, Uttarakhand, India.

*Corresponding author: rahul.khadwalia@gmail.com

\section{ARTICLE INFO}

Received 5. 9. 2019

Revised 9. 11. 2020

Accepted 11.11.2020

Published 1. 4. 2021

Regular article open $\partial_{\text {ACCESS }}$

\begin{abstract}
The main objective of the current research work was to investigate the physicochemical properties of ice samples collected from the snout of three important glaciers located in the Garhwal Himalaya along with the psychrophilic microbial diversity. This study was carried out for two years from 2015 to 2016 with two sampling attempts each year. Ice samples were collected from all the pre-identified sampling sites at a depth of $5 \mathrm{~cm}$ to observe and record the characteristics and to isolate and identify the psychrophilic diversity of microorganisms. Overall fourteen physical and chemical properties of ice samples were recorded. The psychrophilic microbial diversity was identified through the morphological, biochemical and MALDI-TOF-MS techniques. The $\alpha$-diversity of microbes in the ice of Satopanth glacier was 17 with 08 bacterial species, 04 actinomycetes species and 05 fungal species. However, the $\alpha$-diversity of microbes in the ice of Bhagirathi-Kharak glacier was also 17 with 06 bacterial species, 05 actinomycetes species and 06 fungal species. The $\alpha$-diversity of microbes in the ice of Gangotri glacier was 19 with 09 bacterial species, 05 actinomycetes species and 05 fungal species. The present research work can be a decent reference for additional investigations in a similar discipline. The available data will also help the researchers to study the psychrophiles, their existence in glaciers and their importance to society.
\end{abstract}

Keywords: Psychrophiles, Physicochemical properties, Glaciers, MALDI-TOF-MS, Garhwal Himalaya

\section{INTRODUCTION}

The Garhwal Himalaya is very rich in terms of the presence of glaciers including one of the biggest, the Gangotri glacier. A total of $13 \%$ of the area of Uttarakhand is permanently covered with snow. More than 15,000 glaciers are present in the Himalaya. A glacier is a large and slow-moving layer of hard ice; this hard ice is formed due to the compacting of snow layers for thousands of years. The glaciers of Garhwal Himalaya are the major source for some of the most important rivers of India including the Ganga and the Yamuna. The Ganga River has its origin from the Gangotri glacier while Yamuna River has its origin from the Yamunotri glacier. Some of the most important and widely known glaciers in the Garhwal Himalaya are Satopanth glacier, Bhagirathi-Kharak glacier, Gangotri glacier, Kirti glacier, Banderpunch glacier, Chorabari glacier, Dokriani glacier, Doonagiri glacier, Chaukhamba glacier and Nanda Devi glacier. Such glacial habitats have extreme environments in terms of very low temperatures. These glaciers support a cold-loving group of microorganisms or psychrophiles. These microbes are playing a key role in the proper functioning of the ecosystem of glaciers. In an ecosystem of a glacier, the algae or cyanobacteria act as primary producers that sustain heterotrophic groups of organisms including insects, ice worms, bacteria, actinomycetes and fungi of the glaciers (Aitchison, 2001; Hoham and Duval, 2001; Segawa et al., 2005). The microbial diversity can sustain nearly in all environments available on the planet Earth. Microbes can take nutrition even from the extreme environmental circumstances for their existence. Extremophiles are the group of microbes that can exist and grow in one of a kind and outrageous conditions including temperature, and $\mathrm{pH}$ (Oarga, 2009). Among these extremophilic microorganisms, the psychrophiles or the cold-loving microbes can sustain at extreme low temperature. Glaciers ice contains extremely low temperatures in comparison to the surroundings.

Only a very few amounts of literature is available in the public domain on the microbial diversity of glaciers. Zhang et al., (2007) have contributed to cultivable bacterial diversity of ice of Himalayan glaciers; Steven et al., (2007) have contributed on the microbial diversity characterization from permafrost ice of the Canadian high Arctic using cultivable and non-cultivable methods; Zhang et al., (2008) have worked on the presence of bacterial diversity in glacial ice of Himalaya; Xiang et al., (2009) contributed on leading bacterial diversity from
Kuytun 51 glaciers; Wu et al., (2012) reported on bacterial diversity from the foreland of the Tibetan No. 1 glacier in China; Gupta et al., (2015) have worked on bacterial diversity in the western cold dessert Himalaya 'Drass'; Zumsteg (2013) has worked on microbial diversity of Damma glacier's forefield; Zeng et al., (2013) contributed on bacterial diversity of Austre Lovenbreen glacier in Svalbard; Choudhari et al., (2013) reported the microbial diversity of Byron glacier in Alaska through metagenomic approach; Hauptmann et al., (2014) reported diversity of bacteria from the North Pole; Chattopadhyay et al., (2014) have contributed on psychrophilic group of bacteria and their applications; Lutz et al., (2015) have contributed on diversity of microbes in glaciers of Iceland; Boetius et al., (2015) worked on the comparison of microbial ecology in two different habitats; Lutz et al., (2016) tried to link the microbial diversity and their functions to sustain the ecosystem of Arctic; Rondon et al., (2016) reported on the cultivable bacterial diversity of Pico Bolivar's glaciers in Venezuelan tropical Andes; Hotaling et al., (2017) contributed on microbial diversity present in mountain glaciers; Margesin and Collins, (2019) reported on the microbial diversity of the cryosphere; Kumar et al., (2019) contributed to microbial diversity of high altitude; Sherpa et al., (2019) reported on bacterial diversity of glaciers located in Sikkim. However, no important research work has been done as such far on the variety of microorganisms found in the ice of glaciers located in the Garhwal Himalaya. Therefore, the contribution on the microbial diversity of the glaciers of the Garhwal Himalaya is very important for academic as well as applied values.

\section{MATERIALS AND METHODS}

\section{Study Area}

Garhwal Himalaya is blessed with several glaciers including one of the largest in the Indian Himalaya. The three important glaciers (Satopanth, Bhagirathi-Kharak and Gangotri) located in the Garhwal Himalayan region of Uttarakhand had been selected as the study area (Figure 1). The Satopanth Glacier is located in the Chamoli district of Uttarakhand. It sprawls over an area of about $20 \mathrm{Km}^{2}$ (Figure 2). This glacier is one of the most famous and important glaciers of Garhwal Himalaya; as it is one of the significant wellsprings of water in the Alaknanda 
River. The snout of Satopanth glacier is placed at an elevation of $3,810 \mathrm{~m}$ above m.s.l. between latitude $30^{\circ} 44.694^{\prime} \mathrm{N}$ and longitude $79^{\circ} 29.594^{\prime} \mathrm{E}$. BhagirathiKharak Glacier is located at the head of Alaknanda valley in Chamoli district of Uttarakhand. It sprawls over an area of about $30 \mathrm{Km}^{2}$ (Figure 2). BhagirathiKharak glacier also contributes to the origin of the Alaknanda River along with Satopanth glacier. The snout of Bhagirathi-Kharak glacier is situated at an elevation of $3,635 \mathrm{~m}$ above m.s.l. The snout is located between latitude $30^{\circ} 46.955^{\prime} \mathrm{N}$ and longitude $79^{\circ} 24.915^{\prime} \mathrm{E}$. Gangotri Glacier is one among the largest glaciers available in the Himalayan region of India with the easiest trek to reach. It is situated in Uttarakashi district of Uttarakhand between latitude $30^{\circ} 43^{\prime} 22^{\prime \prime}$ to $30^{\circ} 55^{\prime} 49^{\prime \prime} \mathrm{N}$ and longitude $79^{\circ} 04^{\prime} 41^{\prime \prime}$ to $79^{\circ} 16^{\prime} 34^{\prime \prime} \mathrm{E}$. This glacier is considered to be the primary and important source of water for River Ganga. The Gangotri glacier is about $30.2 \mathrm{Km}^{2}$ in length and 1.5 to $3.0 \mathrm{Km}^{2}$ in width (Figure 2). Mt. Shivling, Meru Peak and Bhagirathi III peak are visible en route to the glacier. The snout of this glacier is a grey-blue wall with a tunnel-like structure of a horseshoe shape.

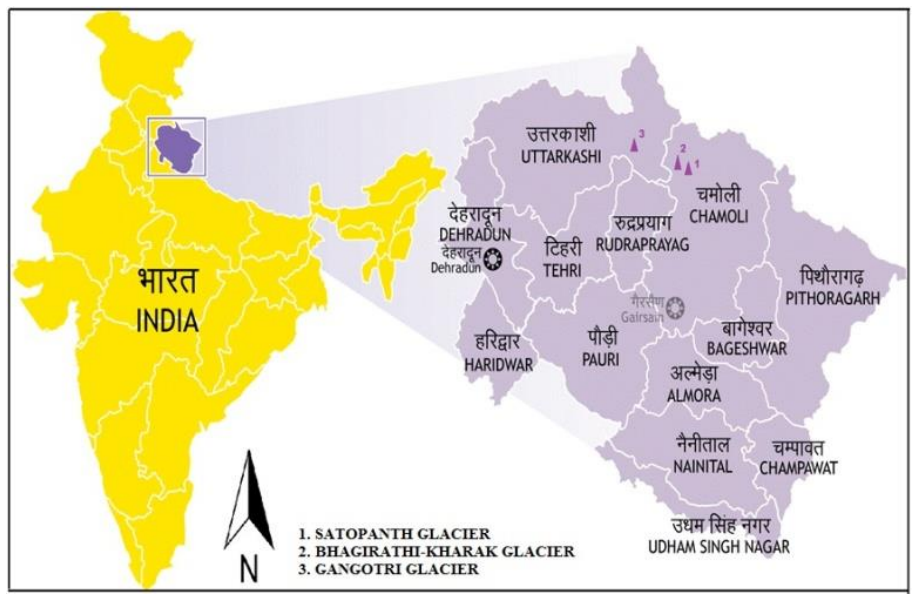

Figure 1 Location of sampling sites of glaciers in the Garhwal Himalaya
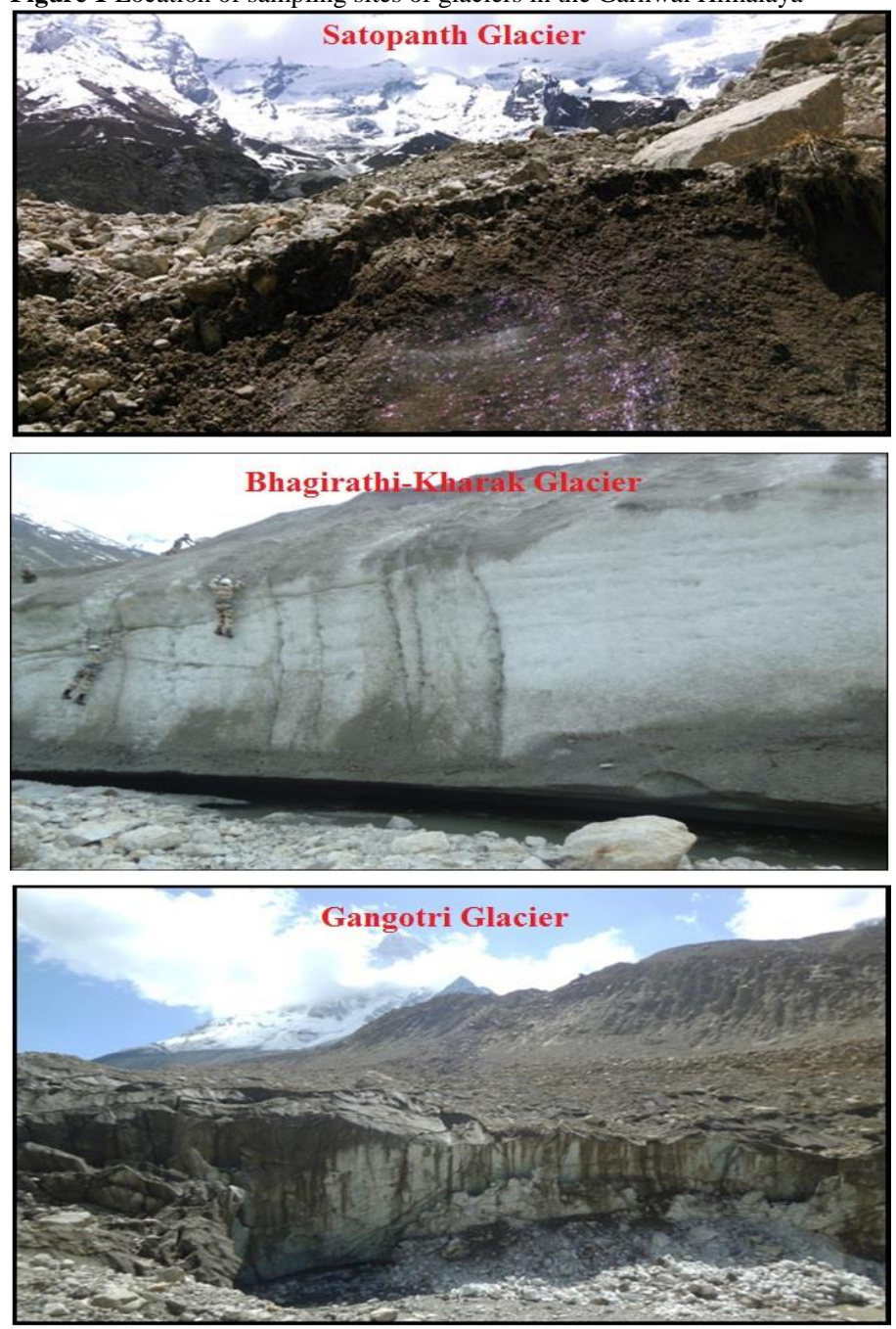

Figure 2 Site images of glaciers located in the Garhwal Himalaya

\section{Sampling of Ice}

Samples of ice at the depth of $5 \mathrm{~cm}$ of the snouts from all the three glaciers were collected and analyzed for a period of two years $(2015 ; 2016)$ in two sampling attempts each year. Sampling operations were made during the June and August months only, due to the locations in the high reaches. Ice samples were collected from the glaciers either in an insulated ice box or thermosteel flask. These collected ice samples were evaluated at the Department within 24 hours of sample collection. Air temperature, Ice temperature and $\mathrm{pH}$ were observed and recorded at the site. However, the left over attributes were evaluated in the Laboratory following the standard protocols mentioned in APHA, (2012); Microbail diversity were analyzed by following the approved protocols mentioned in Morello et al., (2003).

\section{Physical and chemical parameters}

Ice samples were collected from every one of the three icy masses or glaciers for the evaluation of a predefined set of fourteen physicochemical attributes. The air and ice temperatures were observed by a digital thermometer having temperature range between -50 to $+300^{\circ} \mathrm{C}$. $\mathrm{pH}$ was recorded at the study area by using handy $\mathrm{pH}$ meter of Electronics India (Model No. 7011) and in the laboratory by using a laboratory $\mathrm{pH}$ Multiparameter Analyzer of Toshcon company (Model No. TPC17). Electrical conductivity, the concentration of salinity and the amount of TDS were estimated by the utilizing the Multiparameter Analyzer (Toshcon, Model No. TPC-17). However, the concentration of total alkalinity, chlorides, the concentration of total hardness, Calcium and Magnesium were observed by using the methodology mentioned in APHA, (2012). Estimation of Nitrates, Sulphates and Phosphates concentrations in the ice samples were performed by utilizing the UV-VIS Spectrophotometer (Systronic, Model No. 117) at the Department (Kumar and Sharma, (2019 \& 2020a; 2020b).

\section{Microbial isolation and enumeration}

The Nutrient Agar Media (HiMedia) was used to isolate the viable cells of bacteria. However, the Sabaroud Dextrose Agar (HiMedia) commonly known as SDA Media was used to isolate the viable fungal cells. To evade any kind of bacterial undesirable contamination during the isolation of viable fungal cells, the Sabaroud Dextrose Agar media was enriched with $50 \mathrm{mg} . \mathrm{l}^{-1}$ of Ampicillin and 50 mg. $1^{-1}$ of Streptomycin. The Actinomycetes Isolation Agar media (HiMedia) commonly known as AIA Media was used to isolate the viable actinomycetes cells. The $\mathrm{pH}$ of growth media (N.A.; S.D.A. and A.I.A.) used for the isolation of microbes was adjusted similar to the $\mathrm{pH}$ observed at the study area. After the isolation of microbial colonies, the viable cells were streaked on different plates having desirable media to get the pure culture of each microbial strain (Clesceri et al., 1998).

\section{Morphological and biochemical features}

An aggregate of 27 morphological and biochemical attributes were investigated during the examination time frame. During the investigation, pure microbial cells were deliberately analyzed by naked eyes and under a phase-contrast microscope fitted with the MIPS (Microscopic Image projection System) unit (Nikon, Eclipse TS100) to depict the morphology of the bacterial strains. The morphological appraisal included shape, size, edge, height, colour, cell shape, motility, spore formation, flagellation pattern, and gram staining (Kumar et al., 2020). Different biochemical tests were performed to distinguish a microbial strain up to the most reduced conceivable taxon (Rohomania et al., (2015); Ayitso and Onyango, (2016). The tests incorporated the evaluation of catalase, citrate, urease, fructose, methyl red and Voges-Proskauer, indole test, maltose, and so on.

\section{Identification of microbial isolates}

Pure culture of each isolate was sent to the National Centre for Microbial Resources (NCMR), Pune for final confirmation by using the MALDI-TOF Mass Spectrometry. Few of the isolates have been shown in figure 3. Matrix-assisted laser desorption/ionization-time of flight (MALDI-TOF) mass spectrometer is one of the most mainstream MS instruments utilized in the field of science, because of its quick and accurate identification of the genus and species of Gramnegative and Gram-positive bacteria. The identification of microbes by using Mass spectrometry depends on the characteristic spectrum of every species and afterward coordinated with a huge database inside the instrument (Tsung-Yun $\boldsymbol{e t}$ al., 2019). 


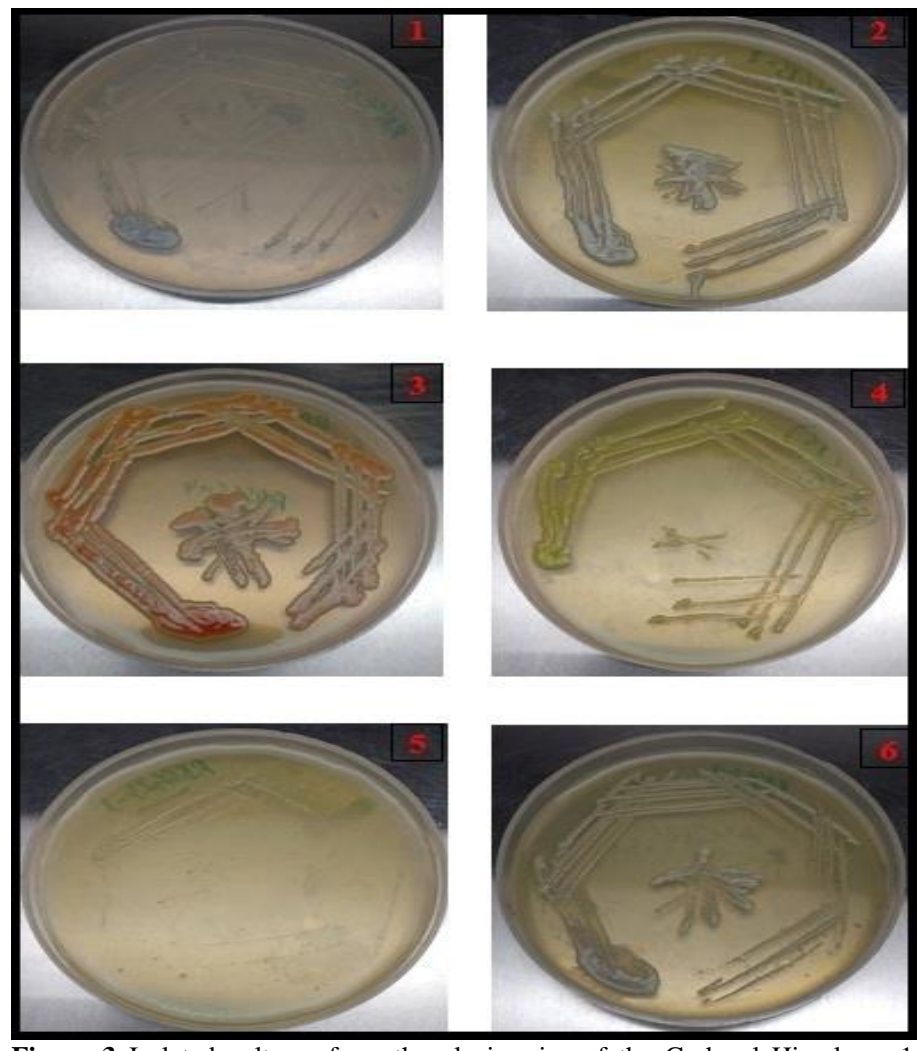

Figure 3 Isolated cultures from the glaciers ice of the Garhwal Himalaya; 1 : Bacillus licheniformis; 2: Arthrobacter sulfonivorans; 3: Arthrobacter oryzae; 4 Microbacterium phyllosphaerae; 5: Arthrobacter polychromogenes; 6: Arthrobacter oxydans

\section{Statistical analysis}

Statistical treatments of data (minimum; maximum; mean; standard deviation) of the physical and chemical attributes of ice of all the three glaciers (Satopanth, Bhagirathi-Kharak and Gangotri Glaciers) were also performed by using Microsoft Office 2013.

Table 1 Physico-chemical characteristics of ice

\begin{tabular}{|c|c|c|c|c|c|c|c|c|c|}
\hline \multirow{2}{*}{$\begin{array}{l}\text { Physico-chemical } \\
\text { Parameters }\end{array}$} & \multicolumn{3}{|c|}{ Satopanth glacier } & \multicolumn{3}{|c|}{ Bhagirathi-Kharak glacier } & \multicolumn{3}{|c|}{ Gangotri glacier } \\
\hline & Min. & Max. & Mean \pm SD & Min. & Max. & Mean \pm SD & Min & $\operatorname{Max}$ & Mean $\pm \mathrm{SD}$ \\
\hline Air Temperature $\left({ }^{\circ} \mathrm{C}\right)$ & 11.4 & 14.5 & $12.88 \pm 1.39$ & 2.5 & 3.4 & $3.0 \pm 0.40$ & 12.0 & 18.0 & $15.0 \pm 2.58$ \\
\hline Ice Temperature $\left({ }^{\circ} \mathrm{C}\right)$ & -0.3 & -0.1 & $-0.2 \pm 0.10$ & -0.4 & -0.2 & $-0.3 \pm 0.10$ & -0.7 & -0.3 & $-0.5 \pm 0.17$ \\
\hline $\mathrm{pH}$ & 6.9 & 7.1 & $7.0 \pm 0.1$ & 7.1 & 7.4 & $7.3 \pm 0.13$ & 6.7 & 7.1 & $6.9 \pm 0.17$ \\
\hline Conductivity ( $\mu \mathrm{S} / \mathrm{cm})$ & 141 & 146 & $143.5 \pm 2.38$ & 70.0 & 73.0 & $71.3 \pm 1.26$ & 102 & 106 & $104.5 \pm 1.73$ \\
\hline Salinity $\left({ }^{\mathrm{SAL}}\right.$ ) & 0.1 & 0.1 & $0.1 \pm 0.0$ & 0 & 0.1 & $0.1 \pm 0.06$ & 0.1 & 0.1 & $0.1 \pm 0.0$ \\
\hline TDS (mg. $\left.1^{-1}\right)$ & 70.0 & 75.0 & $72.25 \pm 2.22$ & 37 & 41 & $39.25 \pm 1.71$ & 50.3 & 52.9 & $51.3 \pm 1.14$ \\
\hline Chlorides $\left(\mathrm{mg} . \mathrm{l}^{-1}\right)$ & 25.56 & 29.82 & $27.69 \pm 2.46$ & 8.52 & 12.78 & $10.65 \pm 1.83$ & 22.72 & 28.40 & $26.27 \pm 2.72$ \\
\hline Total Alkalinity $\left(\mathrm{mg} . \mathrm{l}^{-1}\right)$ & 95 & 115 & $105 \pm 9.13$ & 30.0 & 45.0 & $40.0 \pm 7.07$ & 80.0 & 90.0 & $85.0 \pm 4.08$ \\
\hline Nitrates $\left(\mathrm{mg} .1^{-1}\right)$ & 0.924 & 0.935 & $0.929 \pm 0.00$ & 0.587 & 0.603 & $0.596 \pm 0.01$ & 1.789 & 1.815 & $1.801 \pm 0.01$ \\
\hline Sulphates $\left(\mathrm{mg} \cdot \mathrm{l}^{-1}\right)$ & 1.689 & 1.761 & $1.726 \pm 0.03$ & 0.424 & 0.453 & $0.435 \pm 0.01$ & 1.503 & 1.515 & $1.510 \pm 0.01$ \\
\hline Phosphates (mg..$^{-1}$ ) & 0.181 & 0.187 & $0.184 \pm 0.00$ & 0.063 & 0.069 & $0.066 \pm 0.00$ & 0.957 & 0.985 & $0.970 \pm 0.01$ \\
\hline Total Hardness (mg..$^{-1}$ ) & 32 & 38 & $35.5 \pm 3.0$ & 24.0 & 26.0 & $25.5 \pm 1.0$ & 32.0 & 36.0 & $33.5 \pm 1.91$ \\
\hline Calcium (mg. $\left.\mathrm{l}^{-1}\right)$ & 11.22 & 12.8 & $11.81 \pm 0.76$ & 6.41 & 8.80 & $7.80 \pm 1.20$ & 18.4 & 22.4 & $20.41 \pm 1.90$ \\
\hline Magnesium (mg..$\left.^{-1}\right)$ & 1.0 & 2.44 & $1.48 \pm 0.68$ & 1.0 & 1.96 & $1.48 \pm 0.55$ & 2.92 & 5.35 & $4.26 \pm 1.07$ \\
\hline
\end{tabular}

\section{Microbial Diversity}

The $\alpha$-diversity of microbes in the ice of Satopanth glacier was recorded to be seventeen that included eight bacterial species, four actinomycetes species, and five fungal species during the two years of the study period (Table 2). A considerable high bacterial density $\left(12,180 \mathrm{CFU} \cdot \mathrm{ml}^{-1}\right)$ was estimated from the samples of the Satopanth glacier. Zhang et al. (2007) recorded various groups of

\section{RESULTS AND DISCUSSION}

\section{Physicochemical characteristics of glacial ice}

Evaluated data of fourteen physicochemical characteristics of ice samples were recorded under two sampling actions each year during 2015 and 2016 from the Satopanth glacier, Bhagirathi-Kharak glacier and Gangotri glacier of Garhwal Himalaya (Table 1). As the samples were collected during the day time, the range of air temperature was between $11.4^{\circ} \mathrm{C}$ to $14.5^{\circ} \mathrm{C}$ for Satopanth glacier and $12^{\circ} \mathrm{C}$ to $18^{\circ} \mathrm{C}$ for Bhagirathi-Kharak glacier. However, at Gangotri glacier, the samples were collected during the late evening time the range of air temperature was between $2.5^{\circ} \mathrm{C}$ to $3.4^{\circ} \mathrm{C}$. During the study period, the temperature of ice was recorded between $-0.3^{\circ} \mathrm{C}$ to $-0.1^{\circ} \mathrm{C}$ for Satopanth glaciers; $-0.7^{\circ} \mathrm{C}$ to $-0.3^{\circ} \mathrm{C}$ for Bhagirathi-Kharak glacier and $-0.4^{\circ} \mathrm{C}$ to $-0.2^{\circ} \mathrm{C}$ for Gangotri glacier. TDS represents minerals, salts, metals, ions and biological material suspended in water. The minimum and maximum concentration of TDS was $70 \mathrm{mg} . \mathrm{l}^{-1}$ and 75 mg. $\mathrm{l}^{-1}$ for Satopanth glacier; $50.3 \mathrm{mg} . \mathrm{l}^{-1}$ and $52.9 \mathrm{mg} . \mathrm{l}^{-1}$ for Bhagirathi-Kharak glacier and $37 \mathrm{mg} . \mathrm{l}^{-1}$ to $41 \mathrm{mg} \cdot \mathrm{l}^{-1}$ for Gangotri glacier. The range of electrical conductivity in the ice samples was reported from $141 \mu \mathrm{S} / \mathrm{cm}$ to $146 \mu \mathrm{S} / \mathrm{cm}$ in case of Satopanth glacier; $102 \mu \mathrm{S} / \mathrm{cm}$ to $106 \mu \mathrm{S} / \mathrm{cm}$ in case of Bhagirathi-Kharak glacier and $70 \mu \mathrm{S} / \mathrm{cm}$ to $73 \mu \mathrm{S} / \mathrm{cm}$ in case of Gangotri glacier. The total alkalinity concentration was reported from $95 \mathrm{mg} . \mathrm{l}^{-1}$ to $115 \mathrm{mg} . \mathrm{l}^{-1}$ for Satopanth glacier; 80 mg. $1^{-1}$ to $90 \mathrm{mg} .1^{-1}$ for Bhagirathi-Kharak glacier and $30 \mathrm{mg} \cdot \mathrm{l}^{-1}$ to $45 \mathrm{mg} . \mathrm{l}^{-1}$ for Gangotri glacier. Alkalinity represents the entire substances available in ice that have "acid-neutralizing" ability. The alkalinity of water/ice is mainly due to the existence of carbonates, bicarbonates and hydroxyl ions. The glacier ice of Satopanth and Bhagirathi-Kharak was almost neutral having $\mathrm{pH}$ range between 6.9 to 7.1 whereas, slightly alkaline in case of Gangotri glacier having $\mathrm{pH}$ range between 7.1 to 7.4. Concentration of chlorides for Satopanth glacier was between $25.56 \mathrm{mg} . \mathrm{l}^{-1}$ to $29.82 \mathrm{mg} . \mathrm{l}^{-1}$; for Bhagirathi-Kharak glacier between $22.72 \mathrm{mg} .1^{-1}$ to $28.40 \mathrm{mg} . \mathrm{l}^{-1}$ and for Gangotri glacier from $8.52 \mathrm{mg} . \mathrm{l}^{-1}$ to $12.78 \mathrm{mg} . \mathrm{l}^{-1}$. Total hardness in the sample of ice of Satopanth glacier ranged from $32 \mathrm{mg} .1^{-1}$ to 38 mg. $1^{-1}$; in case of Bhagirathi-Kharak glacier it was ranged from $32 \mathrm{mg} . \mathrm{l}^{-1}$ to 36 $\mathrm{mg} . \mathrm{l}^{-1}$ and in case of Gangotri glacier it was recorded between $24 \mathrm{mg} . \mathrm{l}^{-1}$ to 26 mg. $l^{-1}$. Calcium concentration in Satopanth glacier was recorded between 11.22 mg. $\mathrm{l}^{-1}$ to $12.8 \mathrm{mg} . \mathrm{l}^{-1} ; 18.4 \mathrm{mg} . \mathrm{l}^{-1}$ to $22.4 \mathrm{mg} . \mathrm{l}^{-1}$ in Bhagirathi-Kharak glacier and $6.41 \mathrm{mg} . \mathrm{l}^{-1}$ to $8.80 \mathrm{mg} . \mathrm{l}^{-1}$ in Gangotri glacier. Magnesium concentration was observed from $1.0 \mathrm{mg} .1^{-1}$ to $2.44 \mathrm{mg} .1^{-1}$ in Satopanth glacier; $2.92 \mathrm{mg} . \mathrm{l}^{-1}$ to 5.35 mg. $1^{-1}$ in Bhagirathi-Kharak glacier and $1.0 \mathrm{mg} . \mathrm{l}^{-1}$ to $1.96 \mathrm{mg} . \mathrm{l}^{-1}$ in Gangotri glacier. Salinity in all the samples was recorded between $0.0^{\mathrm{SAL}}$ to $0.1^{\mathrm{SAL}}$ during the study period. The concentration of nitrates was recorded from $0.924 \mathrm{mg} . \mathrm{l}^{-1}$ to $0.935 \mathrm{mg} .1^{-1}$ in Satopanth glacier; $1.789 \mathrm{mg} .1^{-1}$ to $1.815 \mathrm{mg} . \mathrm{l}^{-1}$ in BhagirathiKharak glacier and $0.587 \mathrm{mg} . \mathrm{l}^{-1}$ to $0.603 \mathrm{mg} . \mathrm{l}^{-1}$ in Gangotri glacier. Sulphates concentration was recorded from $1.689 \mathrm{mg} . \mathrm{l}^{-1}$ to $1.761 \mathrm{mg} . \mathrm{l}^{-1}$ for Satopanth glacier; $1.503 \mathrm{mg} . \mathrm{l}^{-1}$ to $1.515 \mathrm{mg} . \mathrm{l}^{-1}$ for Bhagirathi-Kharak glacier and $0.424 \mathrm{mg} . \mathrm{l}^{-}$ ${ }^{1}$ to $0.453 \mathrm{mg} . \mathrm{l}^{-1}$ for Gangotri glacier. Phosphates concentration was observed from $0.181 \mathrm{mg} . \mathrm{l}^{-1}$ to $0.187 \mathrm{mg} . \mathrm{l}^{-1}$ in the ice sample of Satopanth glacier; 0.957 mg. $1^{-1}$ and $0.985 \mathrm{mg} . \mathrm{l}^{-1}$ in Bhagirathi-Kharak glacier and $0.063 \mathrm{mg} . \mathrm{l}^{-1}$ and 0.069 $\mathrm{mg} \cdot \mathrm{l}^{-1}$ in Gangotri glacier. bacteria including Branchy bacterium sp., Acinetobacter sp., Agrococcus sp. from the East Rongbuk (ER) core of Himalayan glacial ice. Microbial diversity of ice of glaciers from Tibetan Plateau was reported by Zhang et al. (2003); Yao et al. (2006). A total of six bacterial species, five actinomycetes species and six fungal species were recorded in the ice samples of Bhagirathi-Kharak glacier where $\alpha$-diversity of microbes was recorded to be seventeen (Table 2). A high density of bacterial density $\left(14,810 \mathrm{CFU} \cdot \mathrm{ml}^{-1}\right)$ has been recorded from the 
Table 2 Microbial diversity dwelling the glaciers of the Garhwal Himalaya

\begin{tabular}{|c|c|c|c|c|}
\hline \multirow{2}{*}{\multicolumn{5}{|c|}{$\begin{array}{l}\text { S. No. Microbial Diversity } \\
\text { A. Bacteria }\end{array}$}} \\
\hline & & & & \\
\hline 1 & Bacillus licheniformis & + & + & - \\
\hline 2 & Bacillus circulans & + & + & + \\
\hline 3 & Staphylococcus aureus & + & + & + \\
\hline 4 & Serratia marcescens & + & - & + \\
\hline 5 & Pseudomonas azatofixans & + & + & + \\
\hline 6 & Pseudomonas fluorescens & + & - & + \\
\hline 7 & Ralstonia eutropha & + & - & - \\
\hline 8 & Staphylococcus cohnii & + & + & - \\
\hline 9 & Vibrio harveyi & - & + & + \\
\hline 10 & Pseudomonas putida & - & - & + \\
\hline 11 & Pseudomonas fragii & - & - & + \\
\hline 12 & Bacillus tequilensis & - & - & + \\
\hline \multicolumn{5}{|c|}{ B. Actinomycetes } \\
\hline 1 & Arthrobacter oxydans & + & + & + \\
\hline 2 & Arthrobacter oryzae & + & + & - \\
\hline 3 & Microbacterium scheliferi & + & - & - \\
\hline 4 & Arthrobacter sulfonivorans & + & - & + \\
\hline 5 & Microbacterium aurum & - & + & - \\
\hline 6 & Microbacterium paraoxydans & - & + & + \\
\hline 7 & Streptomyces rangoon & - & + & - \\
\hline 8 & Microbacterium phyllosphaerae & - & - & + \\
\hline 9 & Microbacterium avium & - & - & + \\
\hline \multicolumn{5}{|c|}{ C. Fungi } \\
\hline 1 & Aspergillus nidulans & + & - & - \\
\hline 2 & Aspergillus terreus & + & - & - \\
\hline 3 & Cladosporium cladosporioides & + & + & - \\
\hline 4 & Curvularia lunata & + & + & - \\
\hline 5 & Phanerochaete chrysosporium & + & - & - \\
\hline 6 & Aspergillus niger & - & + & + \\
\hline 7 & Verticillium nubilum & - & + & - \\
\hline 8 & Verticillium tricorpus & - & + & + \\
\hline 9 & Alternaria radicina & - & + & - \\
\hline 10 & Cladosporium fulvum & - & - & + \\
\hline 11 & Verticillium dahlia & - & - & + \\
\hline \multirow{2}{*}{\multicolumn{2}{|c|}{ a-diversity }} & - & - & + \\
\hline & & 17 & 17 & 19 \\
\hline
\end{tabular}

Table 3 Morphological and biochemical characterization of bacterial isolates from glaciers of the Garhwal Himalaya

\begin{tabular}{|c|c|c|c|c|c|c|c|c|}
\hline \multirow{2}{*}{ Characteristics } & \multicolumn{8}{|c|}{ Bacterial Isolates } \\
\hline & Vibrio harveyi & $\begin{array}{l}\text { Pseudomonas } \\
\text { fluorescens }\end{array}$ & $\begin{array}{l}\text { Microbacterium } \\
\text { paraoxydans }\end{array}$ & $\begin{array}{l}\text { Microbacterium } \\
\text { scheliferi }\end{array}$ & $\begin{array}{l}\text { Ralstonia } \\
\text { eutropha }\end{array}$ & $\begin{array}{l}\text { Serratia } \\
\text { narcescens }\end{array}$ & $\begin{array}{l}\text { Paenibacillus } \\
\text { tzatofixans }\end{array}$ & $\begin{array}{l}\text { Staphylococcus } \\
\text { cohnii }\end{array}$ \\
\hline Shape & Round & Circular & Circular & Circular & Circular & Round & Zircular & Circular \\
\hline Size & $1-3 \mathrm{~mm}$ & $2-3 \mathrm{~mm}$ & $1-3 \mathrm{~mm}$ & $2-4 \mathrm{~mm}$ & $1-3 \mathrm{~mm}$ & $1-2 \mathrm{~mm}$ & $1-3 \mathrm{~mm}$ & $1 \mathrm{~mm}$ \\
\hline Elevation & Centrally raised & Raised & Convex & Raised & Centrally raised & Convex & Flat & Convex \\
\hline Color & Yellow & Cream & Cream & Cream & Cream & Red & Sream & Pale white \\
\hline Cell shape & Rod & Rod & Rod & Rod & Rod & Rod & Rod & Coccoid \\
\hline Flagella & Peritrichous & Peritrichous & Lophotrichous & Monotrichous & Peritrichous & Peritrichous & Peritrichous & Atrichous \\
\hline Catalase & + & + & + & + & + & + & + & + \\
\hline Citrate & + & + & + & + & + & + & + & - \\
\hline Urease & - & - & - & - & - & + & . & + \\
\hline Methyl Red (MR) & + & - & - & - & - & . & . & - \\
\hline Voges Proskauer & - & - & - & - & - & t & . & - \\
\hline Fructose & - & + & + & + & - & + & + & - \\
\hline Sucrose & $\mathrm{v}$ & + & - & - & - & + & + & - \\
\hline Xylose & - & + & + & - & - & . & . & - \\
\hline Trehalose & $\mathrm{v}$ & + & - & - & - & + & + & + \\
\hline Mannose & $\mathrm{v}$ & + & - & - & + & + & . & + \\
\hline Mannitol & $\mathrm{v}$ & - & + & + & - & + & + & - \\
\hline Lactose & - & - & + & - & + & & . & + \\
\hline Maltose & + & - & - & + & - & + & + & - \\
\hline
\end{tabular}

Abbreviations: +: positive; -: negative; v: variable

samples of Bhagirathi-Kharak glacier. Mayilraj et al. (2005) isolated Planococcus stackebrandtii, a novel species from the cold desert of the Indian Himalaya. This novel species was isolated from soil, $0.4 \mathrm{~m}$ depth of an ice glacier at an elevation of 4,200 $\mathrm{m}$ a.s.l. in Spiti Valley of Himachal Pradesh, India However, the $\alpha$-diversity of microbes in Gangotri glacier was recorded to be nineteen during the two years of the study period with nine bacterial species, five actinomycetes species and five fungal species (Table 2). The bacterial density of Gangotri glacier was estimated to be the highest (17,595 CFU.ml ${ }^{-1}$ ) among all these three identified glaciers. Miteva et al. (2004) isolated the microbial diversity from the ice core of a glacier located in Greenland. Mayilraj et al. (2006) isolated a novel species (Dietzia Kunjamensis) from the soil of a glacier located at Himachal Pradesh in India. Zhang et al. (2008) reported $\beta, \gamma$ - 
Proteobacteria and Firmicutes group with dominant taxa of $\gamma$-Proteobacteria from the East Rongbuk (ER) core of the Himalayan glacial ice.

\section{Morphology and Biochemical characteristics of the isolated microbes}

The detailed morphological and biochemical characteristics of few selected microbes (Vibrio harveyi, Pseudomonas fluorescens, Microbacterium paraoxydans, Microbacterium scheliferi, Serratia marcescens, Paenibacillus azatofixans, Ralstonia eutropha, and Staphylococcus cohnii) have been presented in Table 3. Most of the bacteria and actinomycetes isolated from the ice samples of the glaciers (Satopanth, Bhagirathi-Kharak and Gangotri) were found to be Gram positive and most of them are in the form of rods, non-spore forming, nonpigmented and with filamentous branching. Out of the isolated strains, most of the bacteria and actinomycetes are having flagella with the peritrichous pattern.

\section{IMPORTANCE OF PSYCHROPHILES}

Psychrophilic microbial diversity can be utilized as cell processing factories for the production of unstable compounds as well as for bioremediation of contaminated soils and wastewaters. Psychrophiles play important role as environmental cleaners. They effectively degrade pollutants of petroleum hydrocarbons at extremely cold temperatures (Morita, 1975). Cold active enzymes used in order to avoid detrimental effects on taste, texture and nutritional value (Feller and Gerday, 2003). Enzymes produced by psychrophiles used in detergent formulations- lipases, proteases and $\alpha$-enzymes are used to improve the efficiency of detergent and reduce the amount of chemicals used in order to protect the texture and color of fabrics (Hasan et al., 2010). A very few psychrophilic microbial diversity is known to the scientific community. Hence, the current study will help or benefit the future researchers working in the similar aspect that can benefit the human kind.

\section{CONCLUSION}

It has been concluded, that the observations on the present study were made on two important aspects. First aspect was the physicochemical variables of the habitats located in the Garhwal Himalaya and the second aspect was the assessment of diversity and density of microbes. The ice samples were collected from the Satopanth glacier, Bhagirathi-Kharak glacier and Gangotri glacier, which are located at a very high altitude and were accessible only for a limited time period. The $\alpha$-diversity of microbes in Satopanth glacier was found to be seventeen, in Bhagirathi-Kharak glacier it was found to be seventeen and in Gangotri glacier it was found to be nineteen during the study period. The maximum bacterial density in the ice samples of Satopanth glacier was found to be $12,180 \mathrm{CFU} \cdot \mathrm{ml}^{-1}$. It was found to be $14,810 \mathrm{CFU} \cdot \mathrm{ml}^{-1}$ in the ice samples of Bhagirathi-Kharak glacier. However, the bacterial density of Gangotri glacier was estimated to be the highest $\left(17,595\right.$ CFU.ml $\left.{ }^{-1}\right)$ among all these three identified glaciers. The current investigation can give gauge information to additional investigations of the ice sheets and give valuable attributes of indigenous psychrophilic microbial isolates that produce extremozymes which are very useful to various industries including food industries, detergent industries, pharmaceutical industries, etc.

Acknowledgements: One of the authors (Rahul Kumar) is thankfully acknowledge for the fellowship given by the University Grant Commission, New Delhi through Hemvati Nandan Bahuguna Garhwal University (A Central University), Srinagar-Garhwal, Uttarakhand, India for undertaking the present work.

Conflict of interest: The authors declare that they have no conflict of interest.

\section{REFERENCES}

Aitchison, C.W. (2001). The effect of snow cover on small animals, In H.G. Jones, J.W. Pomeroy, D.A. Walker and R.W. Hoham (eds.), Snow Ecology: An Interdisciplinary Examination of Snow-covered Ecosystems. Cambridge University Press, Cambridge, United Kingdom: pp. 229-265

APHA (2012). Standard methods for the estimation of water and wastewater. American Public Health Association, American Waste Water Association and Water Pollution Control Federation. $22^{\text {nd }}$ Edition, Washington.

Ayitso A.S. \& Onyango D.M. (2016). Isolation and identification by morphological and biochemical methods of antibiotic producing microorganisms from the gut of Macrotermes michaelseni in Maseno, Kenya. J. Appl. Biol. Biotechnol. 4: 27-33.

Boetius, A, Anesio, A.M., Deming, J.W., Mikucki, J.A. \& Rapp, J.Z. (2015). Microbial ecology of the cryosphere: Sea ice and glacial habitats. Nature Reviews Microbiology 13(11): 677-690, http://dx.doi.org/ 10.1038/nrmicro3522

Bradley, J.A., Singarayer, J.S., \& Anesio, A.M. (2014). Microbial community dynamics in the forefield of glaciers. Proc $R$ Soc $B$ 281: 1-9, http://dx.doi.org/10.1098/rspb.2014.0882
Chattopadhyay, M.K., Reddy, G.S. \& Shivaji, S. (2014). Psychrophilic bacteria: biodiversity, molecular basis of cold adaptation and biotechnological implications. $\quad$ Current Biotechnology 3(1): 100-116 http://dx.doi.org/10.2174/22115501113026660039

Choudhari, S., Smith, S., Owens, S., Gilbert, J.A., Shain, D.H., Dial, R.J. \& Grigoriev, A. (2013). Metagenome sequencing of prokaryotic microbiota collected from Byron glacier, Alaska. Genome A 1(2): 1-2, http://dx.doi.org/10.1128/genomeA.00099-13

Clesceri, L.S., Greenberg, A.E. \& Eaton, A.D. (1998). Standard Methods for the Examination of Water and Wastewater, 20th edn Baltimore, MA: American Public Health Association, American Water Works Association, Water Environmental Federation.

Feller, G., \& Gerday, C. (2003). Psychrophilic enzymes: Hot topics in cold adaptation. Nat. Rev. Microbiol., 1, 200-2008.

Gupta, P., Sangwan, N., Lal, R. \& Vakhlu, J. (2015). Bacterial diversity of Drass, cold desert in Western Himalaya and its comparison with Antarctic and Arctic. Arch Microbiol . http://dx.doi.org/10.1007/s00203-015-1121-4

Hasan, F., Shah, A.A., Javed, S. \& Hameed, A. (2010). Enzymes used in detergents: Lipases. African Journal of Biotechnology. 9(31), 4836-4844.

Hauptmann, A.L., Stibal, M., Baelum, J., Ponten, T.S., Brunak, S., Bowman, J.S., Hansen, L.H., Jacobsen, C.S. \& Blom, N. (2014). Bacterial diversity in snow on North Pole ice floes. Extremophiles. 18(6): 945-951, http://dx.doi.org/10.1007/s00792-014-0660-y

Hoham, R.W. \& Duval, B. (2001). Microbial ecology of snow and fresh water ice with emphasis on snow algae: 168-228. In Jones, H.G., Pomeroy, J.W., Walker, D.A. and Hoham, R.W. (eds.), Snow Ecology: An Interdisciplinary Examination of Snow-Covered Ecosystem. Cambridge University Press, Cambridge, United Kingdom.

Hotaling, S., Hood, E. \& Hamilton, T.L. (2017). Microbial ecology of mountain glacier ecosystems: biodiversity, ecological connections and implications of a warming climate. Environmental Microbiology 19(8): 2935-2948, https://doi.org/10.1111/1462-2920.13766

Kumar, R., \& Sharma, R.C. (2019). Microbial diversity and physico-chemical attributes of two hot water springs in the Garhwal Himalaya, India. Journal of Microbiology, Biotechnology and Food Sciences 8(6): 1249-1253, https://doi.org/10.15414/jmbfs.2019.8.6.1249-1253

Kumar, R., Kirti, V., \& Sharma, R.C. (2020). Thermophilic microbial diversity and physicochemical attributes of thermal springs in the Garhwal Himalaya Environmental and Experimental Biology 18(2): 143-152 https://doi.org/10.22364/eeb.18.14

Kumar, R. \& Sharma, R.C. (2020a). Microbial diversity in relation to physicochemical properties of hot water ponds located in the Yamunotri landscape of Garhwal Himalaya. Heliyon 6(9):e04850, https://doi.org/10.1016/j.heliyon.2020.e04850

Kumar, R., \& Sharma, R.C. (2020b). Determination of Microbial Diversity and Physico-Chemical Characteristics of Two Hot Water Ponds Near

Badrinath Shrine in the Uttarakhand, India. IWRA (India) Journal 9(1): 16-23.

Kumar, S., Suyal, D.C., Yadav, A., Shouche, Y. \& Goel, R. (2019). Microbial diversity and soil physiochemical characteristic of higher altitude. PLoS ONE 14(3): e0213844, https://doi.org/10.1371/journal.pone.0213844

Lutz, S., Anesio, A.M., Edwards, A. \& Benning, L.G. (2015). Microbial diversity on Icelandic glaciers and ice caps. Front Microbiol , 6:1-17, http://dx.doi.org/10.3389/fmicb.2015.00307

Lutz, S., Anesio, A.M., Edwards, A. \& Benning, L.G. (2016). Linking microbial diversity and functionality of Arctic glacial surface habitats. Environmental Microbiology 19(2): 551-565, http://dx.doi.org/10.1111/1462-2920.13494 Margesin, R. \& Collins, T. (2019). Microbial ecology of the cryosphere (glacial and permafrost habitats): current knowledge. Applied Microbiology and Biotechnology 103: 2537-2549, https://doi.org/10.1007/s00253-019-09631-3

Mayilraj, S., Prasad, G.S., Suresh, K., Saini, H.S., Shivaji, S. \& Chakrabarti, T. (2005). Planococcus stackebrandtii sp. nov., isolated from a cold desert of the Himalaya, India. International Journal of Systematic and Evolutionary Microbiology, 55: 91-94, http://dx.doi.org/10.1099/ijs.0.63290-0

Mayilraj, S., Suresh, K., Kroppenstedt, R.M. \& Saini, H.S. (2006). Dietzia kunjamensis sp. nov., isolated from the Indian Himalaya. International Journal of Systematic and Evolutionary Microbiology, 56: 1667-1671, http://dx.doi.org/10.1099/ijs.0.64212-0

Miteva, V.I., Sheridan, P.P. \& Brenley, J.E. (2004). Phylogenetic and physiological diversity of microorganisms isolated from a deep Greenland Glacier ice core. Applied and Environmental Microbiology, 70(1): 202-213, http://dx.doi.org/10.1128/aem.70.1.202-213.2004

Morello, J.A., Granato, P.A. \& Mizer, H.E. (2003). Laboratory manual and workbook in Microbiology. The MacGraw Hill Publication. $7^{\text {th }}$ Edition, 1-285

Morita, R. (1975). Psychrophilic bacteria. Bacteriol Rev., 39, 144-167.

Oarga, A. (2009). Life in extreme environments. Revista De Biologia E Ciencias Da Terra, 9(1): 1-9.

Rohomania T., Saha M.L., Hossain A. \& Rahman M.S. (2015). Morphological and biochemical characterization of bacteria isolated from fresh and salted hilsa Tenualosa ilisha (Hamilton, 1822). Bangladesh J. Microbiol. 32: 07-13. 
Rondón, J., Gómez, W., Ball, M.M., Melfo, A., Rengifo, M., Balcázar, W., Vera, D.D., Quintero, A.B., Briceño, R.V.M. \& Yarzábal, L.A. (2016). Diversity of culturable bacteria recovered from Pico Bolivar's glacial and subglacial environments, at $4950 \mathrm{~m}$, in Venezuelan tropical Andes. Canadian Journal of Microbiology. 62(11): 904-917, http://dx.doi.org/10.1139/cjm-2016-0172

Segawa, Y., Miyamoto, K., Ushida, K., Agata, K., Okada, N. \& Kohshima, S. (2005). Seasonal change in bacterial flora and biomass in mountain snow from Tateyama Mountains, Japan analyzed by $16 \mathrm{~S}$ rRNA gene sequencing and real time PCR. Applied and Environmental Microbiology, 71(1): 123-130, http://dx.doi.org/10.1128/AEM.71.1.123-130.2005

Sherpa, M.T., Najar, I.N., Das, S. \& Thakur, N. (2019). Culture independent bacterial diversity of Changme Khang and Changme Khangpu glaciers of North Sikkim, India. Environmental Sustainability. https://doi.org/10.1007/s42398-01900067-z

Steven, B., Briggs, G., Mckay, C.P., Pollard, W.H., Greer, C.W., Whyte, L.G. (2007). Characterization of the microbial diversity in a permafrost sample from the Canadian high Arctic using culture-dependent and culture-independent methods. FEMS Microbiol Ecol. 59: 513-523, http://dx.doi.org/10.1111/j.15746941.2006.00247.x

Tsung-Yun, H., Chuan, C.N. \& Shih-Hua, T. (2019). Current status of MALDITOF mass spectrometry in clinical microbiology. Journal of Food and Drug Analysis 27(2): 404-414, https://doi.org/10.1016/j.jfda.2019.01.001

Wu, X., Zhang, W., Liu, G., Yang, X., Hu, P., Chen, T., Zhang, G. \& Li, Z. (2012). Bacterial diversity in the foreland of the Tianshan No. 1 glacier, China. Environmental Research Letters, 7(1): 1-9, http://dx.doi.org/10.1088/17489326/7/1/014038

Xing, S.R., Shang, T.C., Chen, Y., Jing, Z.F. \& Yao, T. (2009). Dominant Bacteria and biomass in the Kuytun 51 glacier. Appl Environ Microbiol, 75(22): 7287-7290, http://dx.doi.org/ 10.1128/AEM.00915-09

Yao, T., Xiang, S., Zhang, X., Wang, N. \& Wang, Y. (2006). Microorganisms in the Malan ice core and their relation to climatic and environmental changes, Global Biogeochem Cycles 20, GB1004, http://dx.doi.org/10.1029/2004GB002424

Zeng, Y.X., Yan, M., Yu, Y., Li, H.R., He, J.F., Sun, K. \& Zhang, F. (2013). Diversity of bacteria in surface ice of Austre Lovénbreen glacier, Svalbard. Arch Microbiol, 195: 313-322, http://dx.doi.org/10.1007/s00203-013-0880-z

Zhang, S., Hou, S., Ma, X., Qin, D. \& Chen, T. (2007). Culturable bacteria in Himalayan glacial ice in response to atmospheric circulation. Biogeosciences, 4: 1-9, http://dx.doi.org/10.5194/bg-4-1-2007

Zhang, S., Hou, S., Wu, Y. \& Qin, D. (2008). Bacteria in Himalayan glacial ice and its relationship to dust. Biogeosciences, 5: 1741-1750, https://dx.doi.org/10.5194/bg-5-1741-2008

Zhang, X.J., Ma, X., Yao, T. \& Zhang, G. (2003). Diversity of 16S rRNA and environmental factor influencing bacteria in Malan ice core. Chin Sci Bull 48(11): 1146-1150, http://dx.doi.org/ 10.1007/BF03185770

Zumsteg A 2013. Microbial diversity in the forefield of the receding Damma glacier. Doctoral thesis. Dipl Natw ETH 1-256, https://doi.org/10.3929/ethz-a$\underline{009928742}$ 